\title{
Impacts of Residual Phosphorus on the Production of Cowpea in the Cerrado Region
}

\author{
Jair da Costa Gaspar1, Marileia Barros Furtado', Welder José dos Santos Silva², \\ Isaías dos Santos Reis ${ }^{3}$, Nítalo André Farias Machado ${ }^{*}$, Maryzélia Furtado de Farias ${ }^{\mathbf{1}}$, \\ Jomar Livramento Barros Furtado', Hosana Aguiar Freitas de Andrade', \\ Raquel da Silva Sobral' ${ }^{1}$, Luisa Julieth Parra-Serrano'1, Khalil de Menezes Rodrigues', \\ Raissa Rachel Salustriano Silva-Matos ${ }^{1}$
}

\author{
${ }^{1}$ Center of Agrarian Sciences and Environmental, Federal University of Maranhão, Chapadinha, Brazil \\ ${ }^{2}$ Center of Agrarian Sciences, Federal University of Piauí, Teresina, Brazil \\ ${ }^{3}$ Faculty of Agrarian and Veterinary Sciences, State University Paulista Júlio de Mesquita Filho, UNESP, São Paulo, Brazil \\ ${ }^{4}$ Exact and Technological Science Center, State University of Western Paraná, Cascavel, Brazil \\ Email: *nitalo-farias@hotmail.com
}

How to cite this paper: Gaspar, J. da C., Furtado, M.B., Silva, W.J. dos S., Reis, I. dos S., Machado, N.A.F., de Farias, M.F., Furtado, J.L.B., de Andrade, H.A.F., Sobral, R. da S., Parra-Serrano, L.J., Rodrigues, K. de M. and Silva-Matos, R.R.S. (2018) Impacts of Residual Phosphorus on the Production of Cowpea in the Cerrado Region. American Journal of Plant Sciences, 9, 645-658. https://doi.org/10.4236/ajps.2018.94051

Received: February 7, 2018

Accepted: March 10, 2018

Published: March 13, 2018

Copyright (๑) 2018 by authors and Scientific Research Publishing Inc. This work is licensed under the Creative Commons Attribution International License (CC BY 4.0).

http://creativecommons.org/licenses/by/4.0/ (c) (i) Open Access

\begin{abstract}
Phosphate fertilizers when applied to the soil, besides being harvested by the crops, promote a residual effect that can be offered to subsequent crops. The objective of this research was to evaluate the residual effect of phosphate fertilization applied to maize cultivation on the successor crop, cowpea, in the Cerrado region in Maranhao. The research was carried out in the experimental area of Federal University of Maranhão (UFMA), located in the city of Chapadinha, MA $\left(3^{\circ} 44^{\prime} 30^{\prime \prime} \mathrm{S}, 43^{\circ} 21^{\prime} 37^{\prime \prime} \mathrm{W}\right)$. The experimental design was in randomized blocks, with six treatments and four replications. The treatments were composed of the following residual P doses: 0, 60, 70, 80, 90, $100 \mathrm{~kg} \cdot \mathrm{ha}^{-1}$ of $\mathrm{P}_{2} \mathrm{O}_{5}$. The cultivation of cowpea (cultivar BRS guariba) was sown at a spacing of $1.0 \times 0.20 \mathrm{~m}$. The cowpea proved to be efficient in the use of residual phosphate fertilization, since it promoted grain yield close to the national average. The cultivation of cowpea in previously cultivated areas is feasible, in order to take advantage of the residual phosphate fertilization in the Cerrado of East of Maranhão. The phosphorus dose applied in the predecessor crop corresponding to $80 \mathrm{~kg} \cdot \mathrm{ha}^{-1}$ of $\mathrm{P}_{2} \mathrm{O}_{5}$ promoted higher grain yield (393.44 $\mathrm{Mg} \cdot \mathrm{ha}^{-1}$ ) and a greater profit margin (US \$326.26). Thus, it is feasible to grow cowpea in previously cultivated areas, in order to take advantage of residual phosphate fertilization.
\end{abstract}

\section{Keywords}

Fertilizing, Vigna unguiculata L. Walp, Phosphate Fertilization, Residue 


\section{Introduction}

The production of cowpea (Vigna unguiculata L. Walp) in Brazil is an activity carried out mainly by small producers. However, it assumes an important socioeconomic role, especially for the North and Northeast Regions, as it is one of the main sources of protein and low-cost carbohydrates available in the rural zone [1]. Their cultivation is usually carried out at the end of the rainy season as a strategy to take advantage of the last days of rainfall, usually after maize harvesting, in order to guarantee an additional source of income for producers [2]. We have to consider that when phosphorus fertilizers are applied to the soil, in addition to the immediate use of the crops, they may also have a residual effect to the point of being offered to subsequent crops [1].

The residual effect of phosphate fertilizers depends on factors such as the doses and sources of phosphorus used, method of application of phosphate fertilizers, management, temperature, soil type, application time, soil moisture and type of crop (Coutinho et al., 2014). Therefore, succession of cowpea after maize cultivation is an interesting strategy for the use of phosphate fertilizer residues [3].

There are several factors that influence the efficiency of phosphate fertilization mainly related to soil, plant, management, and the sources of phosphorus used. The main factors related to the agronomic efficiency of the sources are the phosphorus content soluble in the different fractions or extractive solutions (water, neutral ammonium citrate and citric acid) [4].

On the other hand, when phosphatic fertilizers are applied to the soil, besides the immediate use of the crops, they may also have a residual effect that can be offered to subsequent crops [1]. The residual effect of phosphate fertilizers depends on factors such as the doses and sources of phosphorus used, method of application of phosphate fertilizers, management, temperature, soil type, application time, soil moisture and type of crop [5].

The application of phosphate fertilizers in the cultivation in succession of maize-cowpea is a strategy that may favor small producers, who often lack the resources to acquire certain inputs, such as phosphorus, which are essential for the formation of pods and fodder of grains, reflecting crop productivity [6].

In this sense, the residual phosphorus effect in the soil has been evaluated by several authors in common bean as a function of soil $\mathrm{pH}$ [7], in a degraded pasture area [3], and in other crops such as sugarcane [8]. Due to the need for information regarding the use of previous phosphatic fertilizers on successive crops in soils in the East of the state of Maranhao, the present study aimed to evaluate the residual effect of phosphate fertilization applied to maize cultivation on the successor crop, cowpea, in Cerrado of Maranhao region.

\section{Material and Methods}

The research was carried out in the experimental area of the Center of Agrarian and Environmental Sciences of the Federal University of Maranhão, located in the city of Chapadinha in East Maranhense Mesoregion and Microregion of 
Chapadinha, in the state of Maranhão $\left(3^{\circ} 44^{\prime} 30^{\prime \prime} \mathrm{S}, 43^{\circ} 21^{\prime} 37^{\prime \prime} \mathrm{W}\right.$ and $105 \mathrm{~m}$ altitude). The climate is classified according to Köeppen as Aw tropical dry, with annual average temperature of $26.9^{\circ} \mathrm{C}, 63 \%$ relative humidity and annual rainfall of $1670 \mathrm{~mm}$ according to the National Institute of Meteorology [9]. The mean air temperature $\left({ }^{\circ} \mathrm{C}\right)$ and monthly rainfall $(\mathrm{mm})$ data in the period of conduction of the experiment are shown in Figure 1.

The predominant soil of the region is classified as Dystrophic Yellow Latosol, a sandy-loam texture [10]. Before the installation of the experiment, soil samples were collected in the $0-20 \mathrm{~cm}$ layer and sent to the Soil Laboratory of the State University of Maranhão, for their physical (Table 1) and chemical characterization (Table 2). After 30 days prior to sowing of maize, soil preparation was carried out, consisting of a plowing and harvesting, and then two tons of dolomitic limestone (PRNT $=85 \%)$ were incorporated into the soil in order to increase the base saturation to $70 \%$.

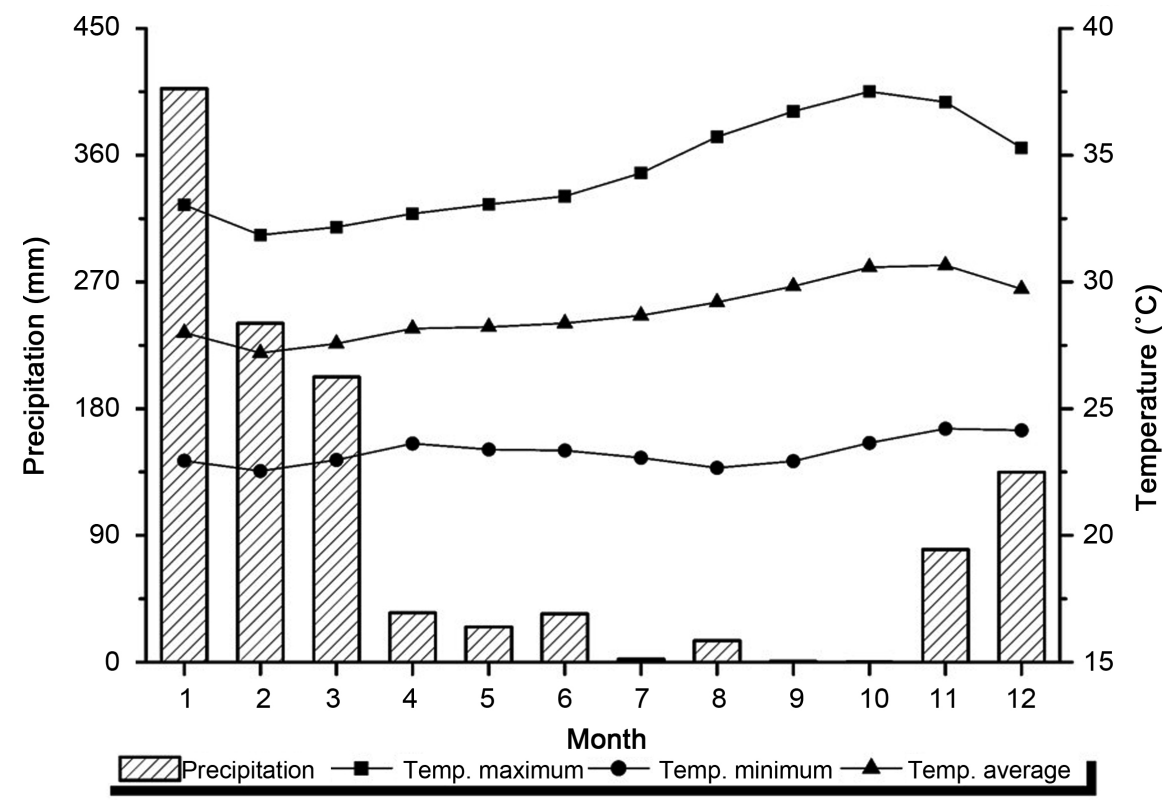

Figure 1. Distribution of rainfall and mean air temperature in Chapadinha-MA, in 2012. Source: INMET.

Table 1. Physical soil characterization of the experimental area at depth $0-20 \mathrm{~cm}$ before maize management and sowing.

\begin{tabular}{ccccc}
\hline Gritstone & Fine sand & Clay & Silt & Soil texture \\
\hline $25.80 \mathrm{~g} \cdot \mathrm{kg}^{-1}$ & $53.50 \mathrm{~g} \cdot \mathrm{kg}^{-1}$ & $8.60 \mathrm{~g} \cdot \mathrm{kg}^{-1}$ & $12.10 \mathrm{~g} \cdot \mathrm{kg}^{-1}$ & Sandy \\
\hline
\end{tabular}

Table 2. Chemical soil characteristics of the experimental area at depth $0-20 \mathrm{~cm}$ before maize management and sowing.

\begin{tabular}{cccccccccc}
\hline $\mathrm{pH}$ & $\mathrm{MO}$ & $\mathrm{P}$ resine & $\mathrm{H}+\mathrm{Al}$ & $\mathrm{K}$ & $\mathrm{Ca}$ & $\mathrm{Mg}$ & $\mathrm{SB}$ & $\mathrm{CTC}$ & $\mathrm{V} \%$ \\
\hline $\mathrm{CaCl}_{2}$ & $\mathrm{~g} \cdot \mathrm{dm}^{-3}$ & $\mathrm{mg} \cdot \mathrm{dm}^{-3}$ & - & ---1 & \\
\hline 6.9 & 19.0 & 17.0 & 1.0 & 1.6 & 0.5 & 0.9 & 6.06 & 7.06 & 86.0 \\
\hline
\end{tabular}


The experimental area was divided into 24 plots of $50 \mathrm{~m}^{2}(5 \times 10 \mathrm{~m})$, where corn was sown in January 2012, with spacing of $1 \times 0.20 \mathrm{~m}$, with five planting lines per plot, discarding $0.50 \mathrm{~m}$ of its extremities. The cultivar AG1051, an early-cycle double hybrid, was used. The fertilization was carried out based on the soil analysis and according to the recommendation for maize crop, except for the source of phosphorus (simple superphosphate), which were applied in the corn plots at different levels $\left(0,60,70,80,90,100 \mathrm{~kg} \cdot \mathrm{ha}^{-1}\right.$ of $\left.\mathrm{P}_{2} \mathrm{O}_{5}\right)$ in order to evaluate its residual effect on the succession crop, cowpea.

They applied $18 \mathrm{~kg} \cdot \mathrm{ha}^{-1}$ of urea and $104 \mathrm{~kg} \cdot \mathrm{ha}^{-1}$ of potassium chloride and 72 $\mathrm{kg} \cdot \mathrm{ha}^{-1}$ of urea were applied in sowing at 25 days after emergence. The other cultural dealings were made as needed. Green maize was harvested at the beginning of June 2012 and, shortly thereafter, new soil samples were collected for quantification of nutrient contents expressed in Table 3.

Afterwards, the opening of pits for the sowing of the cowpea, as a successive crop, was carried out on the corn straw. The cultivar BRS Guariba was used that has an indeterminate growth habit, short branches, semi-erect size and maturation cycle of 65 to 70 days. The experimental design was a randomized complete block design, containing six treatments and four replications, totaling 24 plots. The treatments consisted of doses of residual $\mathrm{P}$ from maize fertilization, as follows: $0,60,70,80,90$ and $100 \mathrm{~kg} \cdot \mathrm{ha}^{-1}$ of $\mathrm{P}_{2} \mathrm{O}_{5}$.

The sowing fertilization for cowpea was recommended according to the soil analysis, which consisted only of potassium, in which $51.72 \mathrm{~kg} \cdot \mathrm{ha}^{-1}$ of potassium chloride were used in all plots. Nitrogen fertilization was excused due to soil organic matter content, which was found to be in an average of $19 \mathrm{~g} \cdot \mathrm{dm}^{-3}$, where it should only be carried out in newly deforested areas or in sandy soils with organic matter content less than $10 \mathrm{~g} \cdot \mathrm{kg}^{-1}$ [11].

Cowpea seeds were inoculated with turfous inoculant (concentration of $5 \times$

Table 3. Chemical characterization of the soil of the experimental area after maize harvest.

\begin{tabular}{ccccccc}
\hline \multirow{2}{*}{ Parameters } & \multicolumn{7}{c}{ P residual em kg.ha-1 $\mathrm{de}_{2} \mathrm{O}_{5}$} \\
\cline { 2 - 7 } & 0 & 60 & 70 & 80 & 90 & 100 \\
\hline $\mathrm{M} . \mathrm{O}\left(\mathrm{g} \cdot \mathrm{dm}^{3}\right)$ & 20.0 & 17.0 & 19.0 & 19.0 & 21.0 & 18.0 \\
$\mathrm{pH}$ & 4.8 & 5.8 & 5.2 & 4.8 & 5.1 & 5.3 \\
$\mathrm{H}+\mathrm{Al}$ & 29.0 & 15.0 & 26.0 & 28.0 & 24.0 & 19.0 \\
$\mathrm{~K}$ & 1.0 & 0.9 & 1.0 & 1.1 & 1.1 & 0.8 \\
$\mathrm{Ca}$ & 15.0 & 31.0 & 22.0 & 18.0 & 19.0 & 21.0 \\
$\mathrm{Mg}$ & 5.0 & 3.0 & 4.0 & 1.0 & 7.0 & 5.0 \\
$\mathrm{~S} . \mathrm{B}$ & 21.0 & 34.9 & 27.0 & 20.1 & 27.1 & 26.8 \\
$\mathrm{CTC}$ & 50.0 & 49.9 & 53.0 & 48.1 & 51.1 & 45.8 \\
$\mathrm{P}\left(\mathrm{mg} \cdot \mathrm{dm}{ }^{-3}\right)$ & 3.0 & 22.0 & 13.0 & 12.0 & 12.0 & 11.0 \\
$\mathrm{~V}(\%)$ & 42.0 & 70.0 & 51.0 & 42.0 & 53.0 & 59.0 \\
$\mathrm{~K} / \mathrm{CTC}(\%)$ & 2.0 & 1.8 & 1.9 & 2.3 & 2.2 & 1.7 \\
$\mathrm{Mg} / \mathrm{CTC}(\%)$ & 10.0 & 6.0 & 7.5 & 2.1 & 13.7 & 10.9 \\
\hline
\end{tabular}


$10^{9} \mathrm{~g}^{-1}$ cells), which contained the strain SEMIA 5079 and SEMIA 5080 of Bradyrhizobium japonicum. The inoculation was carried out by pre-wetting the seeds with a sugar solution $\left(0.1 \mathrm{~g} \cdot \mathrm{ml}^{-1}\right.$ concentration), according to the manufacturer's recommendation. Seeding was carried out soon after inoculation of the seeds, on June 11, 2012. During the crop cycle, a supplementary irrigation depth of $115 \mathrm{~mm}$ was applied to meet the crop water requirements, using a conventional sprinkler irrigation system with a flow rate of $3.6 \mathrm{~m}^{3} \cdot \mathrm{h}^{-1}$. The applications were performed with three days watering and each application, with a blade of $6.8 \mathrm{~mm}$.

Three plants were selected at random from each plot, which were identified with a red ribbon to perform the variables plant height (PH) and stem diameter (ST) at 15 and 30 DAE (days after the experience). Ten whole plants were collected in the experimental plot at 15 and $30 \mathrm{DAE}$ to evaluate the following variables: main root length (MRL), fresh shoot mass (FSM), dry shoot mass (DSM), fresh root mass (FRM), and root dry mass (RDM); (NRP), nodule diameter (DN), fresh nodule mass (FNM) and nodule dry mass (NDM), as well as the number of secondary root nodules were analyzed.

To determine the leaf area, leaves of the last trefoiled were collected per plot at 15 and $30 \mathrm{DAE}$. The leaves were then scanned and analyzed by software image tool 3.0 [12]. Three harvested cowpea were done at 61, 66 and 68 DAS, followed by evaluations of the production components (pod length, number of pod-1 grains, number of plant ${ }^{-1}$ pods and yield of grains, is adjusted to $13 \%$ moisture) in ten plants randomly selected in each plot.

The economic analysis of the evaluated treatments was carried out taking into consideration the economic return only of the costs with phosphate fertilization. Net Revenue (NR) was obtained by difference between Gross Revenue (GR) and Costs $(\mathrm{C})(\mathrm{NR}=\mathrm{GR}-\mathrm{C})$, considering the local price of the simple superphosphate of US $\$ 229.44$ per ton and the bag of cowpea of US $\$ 52.46$.

Data were submitted were submitted to the normality test (Shapiro Wilk, $\mathrm{P}<$ 0.05 ), and to analysis of variance (ANOVA), according to the statistical model: $Y i j=\mu+B i+F j+E i j$, where: $Y i j$ is dependent variable; $\mu$ is the general mean, Bi is the effect of the ith block; Fk is the effect of the kth level of residual phosphorus and Eijk is the experimental error, assuming Eijk $~ \operatorname{NID}\left(0, \sigma^{2}\right)$, and compared by the Duncan test (coefficient of variation-CV $<50 \%$ ) and Kruskal-Wallis test (non-parametric test) $(\mathrm{CV}>50 \%)[13]$.

\section{Results and Discussion}

There was no influence of residual phosphorus doses for the plant height $(\mathrm{PH})$ and main root length (MRL) variables at 15 and 30 days after emergence (AE) (Table 4), which may be justified by the possible underestimation of for this crop, since according to [5], higher doses than those proposed in this trial, around $200 \mathrm{~kg} \cdot \mathrm{ha}^{-1}$ of $\mathrm{P}_{2} \mathrm{O}_{5}$, would be required.

Residual effect of phosphate fertilizations under cowpea cultivation in the 
Table 4. Average plant height (PH), main root length (MRL), stem diameter (SD) and leaf area (LA) results at 15 and $30 \mathrm{DAE}$.

\begin{tabular}{|c|c|c|c|c|}
\hline $\begin{array}{c}\text { Residual } \mathrm{P} \\
\left(\mathrm{kg} \cdot \mathrm{ha}^{-1} \text { of } \mathrm{P}_{2} \mathrm{O}_{5}\right)\end{array}$ & $\mathrm{PH}(\mathrm{cm})$ & MRL $(\mathrm{cm})$ & $\mathrm{SD}(\mathrm{cm})$ & LA $\left(\mathrm{cm}^{2}\right)$ \\
\hline \multicolumn{5}{|c|}{$15 \mathrm{DAE}$} \\
\hline 0 & $10.82 \mathrm{a}$ & $11.46 \mathrm{a}$ & $0.39 \mathrm{~b}$ & $16.52 \mathrm{a}$ \\
\hline 60 & $11.46 \mathrm{a}$ & $10.75 \mathrm{a}$ & $0.48 \mathrm{a}$ & $20.66 \mathrm{a}$ \\
\hline 70 & $11.76 \mathrm{a}$ & $10.76 \mathrm{a}$ & $0.48 \mathrm{a}$ & $20.73 \mathrm{a}$ \\
\hline 80 & $12.25 \mathrm{a}$ & $11.74 \mathrm{a}$ & $0.44 \mathrm{ab}$ & $18.68 \mathrm{a}$ \\
\hline 90 & $12.01 \mathrm{a}$ & $16.92 \mathrm{a}$ & $0.44 \mathrm{ab}$ & $21.21 \mathrm{a}$ \\
\hline 100 & $11.36 \mathrm{a}$ & $10.95 \mathrm{a}$ & $0.48 \mathrm{a}$ & $16,16 \mathrm{a}$ \\
\hline CV\% & 7.67 & 42.68 & 11.69 & 19.21 \\
\hline \multicolumn{5}{|c|}{$30 \mathrm{DAE}$} \\
\hline 0 & $20.30 \mathrm{a}$ & $14.92 \mathrm{a}$ & $0.58 \mathrm{a}$ & $29.64 \mathrm{~b}$ \\
\hline 60 & $20.86 \mathrm{a}$ & $14.43 \mathrm{a}$ & $0.63 \mathrm{a}$ & $36.86 \mathrm{a}$ \\
\hline 70 & $21.48 \mathrm{a}$ & $18.08 \mathrm{a}$ & $0.63 \mathrm{a}$ & $33.29 \mathrm{ab}$ \\
\hline 80 & $25.42 \mathrm{a}$ & $14.76 \mathrm{a}$ & $0.62 \mathrm{a}$ & $34.86 \mathrm{ab}$ \\
\hline 90 & $22.92 \mathrm{a}$ & $15.95 \mathrm{a}$ & $0.55 \mathrm{a}$ & $31.43 \mathrm{ab}$ \\
\hline 100 & $20.86 \mathrm{a}$ & $19.24 \mathrm{a}$ & $0.57 \mathrm{a}$ & $32.66 \mathrm{ab}$ \\
\hline CV\% & 15.55 & 20.38 & 15.96 & 12.93 \\
\hline
\end{tabular}

Means followed by the same letter in the column do not differ by Duncan test at the $5 \%$ meaningfulness level. CV: coefficient of variation.

state of Paraíba, with doses of 0 to $160 \mathrm{~kg} \cdot \mathrm{ha}^{-1}$ of $\mathrm{P}_{2} \mathrm{O}_{5}$ in maize (predecessor) [14]. The authors did not find significant effect of residual $P$ for root length (RL), as reported in the present study.

As for the diameter of the stem (SD), it is possible to observe that the doses of 60,70 and $100 \mathrm{~kg} \cdot h a^{-1}$ of residual $\mathrm{P}_{2} \mathrm{O}_{5}$ promoted higher SD at $15 \mathrm{DAE}$, differing $(\mathrm{P}<0.05)$, however, only the treatment without this nutrient, but at $30 \mathrm{DAE}$, all treatments analyzed were statistically the same. This was due to the higher availability of $\mathrm{P}$ (Table 3 ) for the plants that received phosphate fertilization and its close relationship with resistance to lodging [5].

Evaluating $\mathrm{P}$ doses of up to $210 \mathrm{~kg} \cdot \mathrm{ha}^{-1}$, [15], observed that the increase of $\mathrm{P}$ doses in the soil promotes an increase in the SD, evidencing the relation of $\mathrm{P}$ with lodging resistance. However, in the research conducted by [14]), there was no significant effect for this variable attributed by the authors to the lowest available phosphorus content in Oxisols.

In fact, the results obtained for $\mathrm{SD}$ at 15 and $30 \mathrm{DAE}$ can be explained by the high solubility of the phosphate fertilizers. It is known that when very soluble sources are used in tropical soils, which have a high P fixing capacity, they are converted into forms unavailable to plants, and thus have their efficiency reduced with time [8].

There was no difference $(\mathrm{P}<0.05)$ for leaf area $(\mathrm{LA})$ at $15 \mathrm{DAE}$, but at 30 DAE the residual dose of $60 \mathrm{~kg} \cdot \mathrm{ha}^{-1}$ of $\mathrm{P}_{2} \mathrm{O}_{5}$ promoted higher LA, but did not 
differ, however, from other treatments, except the control. The low concentration of $\mathrm{P}\left(3 \mathrm{mg} \cdot \mathrm{dm}^{-3}\right)$ in the control treatment may be the justification for the lower LA found, since it is known that phosphorus is an element related to photosynthesis of plants [16].

When analyzing the variable fresh mass of the aerial part (MAP) (Table 5), it was observed that there was no influence of the residual doses of phosphorus, at 15 and 30 DAE. There was a difference $(\mathrm{P}<0.05)$ for aerial part dry mass (APDM), in which the residual dose of $90 \mathrm{~kg} \cdot \mathrm{ha}^{-1}$ of $\mathrm{P}_{2} \mathrm{O}_{5}$ promoted higher $\mathrm{APDM}$ at $15 \mathrm{DAE}$, without differing from other treatments except the dose of $100 \mathrm{~kg} \cdot \mathrm{ha}^{-1}$. At $30 \mathrm{DAE}$, the treatment plants with the residual dose of $70 \mathrm{~kg} \cdot \mathrm{ha}^{-1}$ of $\mathrm{P}_{2} \mathrm{O}_{5}$ promoted higher APDM $(\mathrm{P}<0.05)$ without, however, differing from 60 $\mathrm{kg} \cdot \mathrm{ha}{ }^{-1}$ of $\mathrm{P}_{2} \mathrm{O}_{5}$.

The results obtained with the cultivar BRS-Paraguaçu, indicate that the highest values of APDM with the fertilization of $70 \mathrm{~kg} \cdot \mathrm{ha}^{-1}$ of $\mathrm{P}_{2} \mathrm{O}_{5}$ in the forms of single superphosphate are similar to those found in the present research [17]. The leaf area of the cowpea plants at $0.0017 \mathrm{~g}$ for each increment of $1 \mathrm{~kg}$ at baseline levels of $\mathrm{P}_{2} \mathrm{O}_{5}$ [14].

The requirements of $\mathrm{P}$ may be relatively higher for the production of roots than for the production of leaves [18]. The dose of $100 \mathrm{~kg} \cdot \mathrm{ha}^{-1}$ of residual $\mathrm{P}_{2} \mathrm{O}_{5}$ promoted a greater $(\mathrm{P}<0.05)$ dry mass of root $(\mathrm{DMR})$ at $30 \mathrm{DAE}$, possibly

Table 5. Mean fresh shoot mass (FSM), dry shoot mass (DSM), fresh root mass (FRM) and root dry mass $(\mathrm{RDM})$ at 15 and $30 \mathrm{DAE}$.

\begin{tabular}{|c|c|c|c|c|}
\hline $\begin{array}{c}\text { Residual } \mathrm{P} \\
\left(\mathrm{kg} \cdot \mathrm{ha}^{-1} \text { of } \mathrm{P}_{2} \mathrm{O}_{5}\right)\end{array}$ & FSM (g) & $\operatorname{DSM}(\mathrm{g})$ & FRM (g) & RDM (g) \\
\hline \multicolumn{5}{|c|}{$15 \mathrm{DAE}$} \\
\hline 0 & $9.04 \mathrm{a}$ & $1.26 \mathrm{ab}$ & $0.75 \mathrm{a}$ & $0.15 \mathrm{a}$ \\
\hline 60 & $9.59 \mathrm{a}$ & $1.12 \mathrm{ab}$ & $0.69 \mathrm{a}$ & $0.13 \mathrm{a}$ \\
\hline 70 & $10.96 \mathrm{a}$ & $1.28 \mathrm{ab}$ & $0.74 \mathrm{a}$ & $0.16 \mathrm{a}$ \\
\hline 80 & $8.73 \mathrm{a}$ & $1.30 \mathrm{ab}$ & $0.62 \mathrm{a}$ & $0.15 \mathrm{a}$ \\
\hline 90 & $10.96 \mathrm{a}$ & $1.43 \mathrm{a}$ & $0.65 \mathrm{a}$ & $0.15 \mathrm{a}$ \\
\hline 100 & $7.96 \mathrm{a}$ & $0.99 \mathrm{~b}$ & $0.50 \mathrm{a}$ & $0.14 \mathrm{a}$ \\
\hline $\mathrm{CV} \%$ & 21.20 & 21.30 & 27.31 & 15.12 \\
\hline \multicolumn{5}{|c|}{$30 \mathrm{DAE}$} \\
\hline 0 & $40.81 \mathrm{a}$ & $8.12 \mathrm{~b}$ & $2.97 \mathrm{~b}$ & $0.15 \mathrm{~b}$ \\
\hline 60 & $42.71 \mathrm{a}$ & $9.84 \mathrm{ab}$ & $3.75 \mathrm{ab}$ & $0.13 \mathrm{~b}$ \\
\hline 70 & $48.63 \mathrm{a}$ & $12.24 \mathrm{a}$ & $3.38 \mathrm{ab}$ & $0.16 \mathrm{~b}$ \\
\hline 80 & $54.59 \mathrm{a}$ & $8.95 \mathrm{~b}$ & $4.26 \mathrm{a}$ & $0.15 \mathrm{~b}$ \\
\hline 90 & $43.96 \mathrm{a}$ & $7.55 \mathrm{~b}$ & $3.25 \mathrm{ab}$ & $0.15 \mathrm{~b}$ \\
\hline 100 & $42.71 \mathrm{a}$ & $7.61 \mathrm{~b}$ & $3.32 \mathrm{ab}$ & $0.75 \mathrm{a}$ \\
\hline CV\% & 21.13 & 19. 53 & 21.10 & 26.56 \\
\hline
\end{tabular}

Means followed by the same letter in the column do not differ by Duncan test at the $5 \%$ meaningfulness level. CV: coefficient of variation. 
because P is closely related to root growth [19]. Thus, the higher dose allowed greater root development in relation to the other treatments. Vigorous root formation is required for the constant translocation of photoassimilates from the shoot to ensure rates of cell growth and elongation.

In relation to the nodule analysis (Table 6), it was found that the residual doses of phosphorus did not promote significant differences in relation to the number of nodules in the main root (NNMR) and diameter of the main root nodules (MRN). It was also verified that the residual dose of $60 \mathrm{~kg} \cdot \mathrm{ha}^{-1}$ of $\mathrm{P}_{2} \mathrm{O}_{5}$ promoted a higher fresh mass of the main root nodules (MRN) and dry mass of the main root nodules (DMN) at $15 \mathrm{DAE}$, not significantly different from the other treatments, except of the control treatment. There were no significant differences between treatments for MRN and DMN at 30 DAE.

Table 6. Mean results for number of main root nodules (MRN), number of secondary root nodules (NSRN), main root nodule diameter (MRND, in $\mathrm{cm}$ ), fresh root nodule mass (FRNM, in g), and dry mass of root (DMR, in g) nodules at 15 and 30 DAE.

\begin{tabular}{|c|c|c|c|c|c|}
\hline Residual $\mathrm{P}^{*}$ & MRN & NSRN & MRND & FRNM & DMR \\
\hline \multicolumn{6}{|c|}{$15 \mathrm{DAE}$} \\
\hline \multirow{2}{*}{0} & 0.5 & 0.1 & 0.07 & 0.03 & $3.6 \mathrm{E}^{-03}$ \\
\hline & $(0.0-1.0) \mathrm{a}$ & $(0.0-1.0) b$ & $(0.00-0.45) a$ & $(0.00-0.07) b$ & $(0.00-0.01) b$ \\
\hline \multirow{2}{*}{60} & 1.50 & 17.66 & 0.26 & 0.27 & 0.06 \\
\hline & $(0.0-4.6) \mathrm{a}$ & $(0.6-39.6) a$ & $(0.00-0.3) a$ & $\left(4.0 \mathrm{E}^{-03}-0.3\right) \mathrm{a}$ & $\left(2.3 \mathrm{E}^{-03}-0.13\right) \mathrm{a}$ \\
\hline \multirow{2}{*}{70} & 1.3 & 13.5 & 0.1 & 0.15 & 0.04 \\
\hline & $(1.0-3.0) \mathrm{a}$ & $(3.0-15.3) \mathrm{a}$ & $(0.02-0.13) a$ & $\left(4.0 \mathrm{E}^{-03}-0.04\right) \mathrm{ab}$ & $\left(4.0 \mathrm{E}^{-03}-0.04\right) \mathrm{ab}$ \\
\hline \multirow{2}{*}{80} & 0.3 & 7.5 & 0.12 & 0.09 & 0.02 \\
\hline & $(0.0-2.6) \mathrm{a}$ & $(1.6-11.6) a b$ & $(0.0-0.2) \mathrm{a}$ & $(0.01-0.13) a b$ & $\left(3.8 \mathrm{E}^{-03}-0.03\right) \mathrm{ab}$ \\
\hline \multirow{2}{*}{90} & 1.17 & 15.8 & 0.1 & 0.19 & 0.04 \\
\hline & $(0.0-3.6) \mathrm{a}$ & $(0.0-2.6) \mathrm{a}$ & $(0.00-0.33) \mathrm{a}$ & $(0.00-0.26) a b$ & $(0.00-0.07) a b$ \\
\hline \multirow{2}{*}{100} & 0.5 & 8.8 & 0.17 & 0.15 & 0.04 \\
\hline & $(0.0-9.6) a$ & $(1.0-21.6) \mathrm{a}$ & $(0.0-0.2) \mathrm{a}$ & $\left(3.0 \mathrm{E}^{-03}-0.5\right) \mathrm{ab}$ & $\left(1.0 \mathrm{E}^{-03}-0.03\right) \mathrm{ab}$ \\
\hline \multicolumn{6}{|c|}{$30 \mathrm{DAE}$} \\
\hline \multirow{2}{*}{0} & 0.0 & 0.0 & 0.0 & 0.27 & 0.01 \\
\hline & $(0.0-0.0) a$ & $(0.0-1.6) b$ & $(0.0-0.0) \mathrm{a}$ & $(0.00-0.97) a$ & $(0.00-0.21) \mathrm{a}$ \\
\hline \multirow{2}{*}{60} & 0.5 & 5.0 & 0.1 & 0.31 & 0.10 \\
\hline & $(0.0-2.6) a$ & $(1.3-41.0) \mathrm{ab}$ & $(0.0-0.3) \mathrm{a}$ & $(0.03-1.37) \mathrm{a}$ & $(0.01-0.51) \mathrm{a}$ \\
\hline \multirow{2}{*}{70} & 0.5 & 7.0 & 0.05 & 0.42 & 0.06 \\
\hline & $(0.0-6.3) \mathrm{a}$ & $(0.0-20.0) a b$ & $(0.0-0.0) \mathrm{a}$ & $(0.00-0.84) \mathrm{a}$ & $(0.00-0.17) \mathrm{a}$ \\
\hline \multirow{2}{*}{80} & 0.0 & 7.8 & 0.0 & 0.61 & 0.09 \\
\hline & $(0.0-0.0) \mathrm{a}$ & $(2.0-9.0) \mathrm{a}$ & $(0.0-0.5) \mathrm{a}$ & $(0.06-0.96) a$ & $(0.01-0.11) a$ \\
\hline \multirow{2}{*}{90} & 0.5 & 3.3 & 0.12 & 0.25 & 0.07 \\
\hline & $(0.0-2.0) \mathrm{a}$ & $(0.0-23.0) a b$ & $(0.01-0.75) a$ & $(0.01-0.75) a$ & $\left(6.0 \mathrm{E}^{-04}-0.14\right) \mathrm{a}$ \\
\hline \multirow{2}{*}{100} & 1.0 & 4.5 & 0.09 & 0.26 & 0.04 \\
\hline & $(0.0-3.3) \mathrm{a}$ & $(0.0-8.6) a b$ & $(0.00-0.53) \mathrm{a}$ & $(0.00-0.53) \mathrm{a}$ & $(0.00-0.11) \mathrm{a}$ \\
\hline
\end{tabular}

Means followed by the same letter in the column do not differ from each other by the non-parametric analysis performed by the Kruskal-Wallis test at the $5 \%$ meaningfulness level. ${ }^{\star} \mathrm{kg} \cdot \mathrm{ha}^{-1}$ of $\mathrm{P}_{2} \mathrm{O}_{5}$. 
It is possible to observe that, in general, all treatments fertilized with phosphorus promoted a higher number of nodules in the secondary roots (NSR) at 15 and 30 DAE. The importance of this analysis is the close relationship between the efficiency of the $\mathrm{N}_{2}$ fixation process and the availability of $\mathrm{P}$ due to its participation in the symbiotic process. Several studies have already verified the effect of phosphate fertilization on growth and nodulation in leguminous [17] [20].

It is known that $\mathrm{P}$ is an element able to increase the efficiency of nodulation and this happens because the biological fixation of $\mathrm{N}_{2}$ is a process that demands a great energy demand [17]. Since P plays an important role in the energy metabolism of the cells, its deficiency has a negative impact on the energetic state of the nodules [21]. This can be verified with the parameters number of nodules in the secondary root, fresh and dry mass of nodules, in which, the treatment that did not receive phosphorus, presented inferior results to the others

The nodulation of cowpea occurs adequately at doses of approximately 40 $\mathrm{kg} \cdot \mathrm{ha}^{-1}$ of $\mathrm{P}_{2} \mathrm{O}_{5}$ [17]. However, for nodulation evaluations there was no influence of phosphorus doses at $30 \mathrm{DAE}$. This fact happened, possibly, due to the 30 $\mathrm{DAE}$, the plant was in the period of flowering. The flowering period corresponds to the period of maximum nodulation, in other words, occurs at $30 \mathrm{DAE}$ an establishment of the number of nodules, mainly in the main root, reflecting directly in its fresh and dry mass [22].

According to the results shown in Table 7, it can be verified that the residual dose of $80 \mathrm{~kg} \cdot \mathrm{ha}^{-1}$ of $\mathrm{P}_{2} \mathrm{O}_{5}$ promoted higher number of pods per plant (NPP), but did not differ from the other doses, except for the control treatment. For the length of pods (LP) the dose of $60 \mathrm{~kg} \cdot \mathrm{ha}^{-1}$ of $\mathrm{P}_{2} \mathrm{O}_{5}$ promoted higher results, but did not differ from the other treatments, except the control.

The treatments presented pods with a length between $21.61 \mathrm{~cm}$ and $24.32 \mathrm{~cm}$, within commercial standards that is above $20 \mathrm{~cm}$ [23]. On the other hand, the number of pods per plant (NPP) ranging from 4.98 to 2.85 is considered to be out of the species standards, which is at least twenty pods per plant [24]. This fact may be related to water stress during the flowering period, which may provide

Table 7. Average results for Number of Pods per Plant (NPP), Pod Length (PL), Number of Grains per Pod (NGP).

\begin{tabular}{cccc}
\hline Residual $\mathrm{P}^{1}$ & NPP & PL $(\mathrm{cm})$ & NGP \\
\hline 0 & $2.85 \mathrm{~b}$ & $21.61 \mathrm{~b}$ & $13.30 \mathrm{bc}$ \\
60 & $4.65 \mathrm{ab}$ & $24.32 \mathrm{a}$ & $15.18 \mathrm{a}$ \\
70 & $4.55 \mathrm{ab}$ & $23.56 \mathrm{ab}$ & $14.00 \mathrm{ab}$ \\
80 & $4.98 \mathrm{a}$ & $23.16 \mathrm{ab}$ & $13.60 \mathrm{ab}$ \\
90 & $4.78 \mathrm{ab}$ & $23.32 \mathrm{ab}$ & $13.80 \mathrm{ab}$ \\
100 & $4.33 \mathrm{ab}$ & $22.20 \mathrm{ab}$ & $11.90 \mathrm{c}$ \\
$\mathrm{CV} \%$ & 27.17 & 5.88 & 7.19 \\
\hline
\end{tabular}

Means followed by the same letter in the column do not differ by Duncan test at $5 \%$ meaningfulness level. $\mathrm{CV}$ : coefficient of variation. ${ }^{1} \mathrm{~kg} \cdot \mathrm{ha}^{-1}$ of $\mathrm{P}_{2} \mathrm{O}_{5}$. 
a large number of flower abscission [1].

Linear correlation analysis found positive relationships between some analyzed variables; the plant height $(\mathrm{PH})$ had a positive correlation $(\mathrm{P}<0.05)$, with dry mass of root nodules (MRN), dry shoot mass (DSM), leaf area (LA) and grain yield to $15 \mathrm{DAE}$, which means that there is a correlation between these characteristics, that is, the highest response to a plant height variable, simultaneously, there will be increase for NDM, DMA, LA and PROD (Table 8). However, at 30 DAE only NDM and DMA had a positive correlation $(\mathrm{P}<0.01)$ for AP, therefore, no correlation was detected between AP and PROD (Table 9).

The number of nodules in the main root (NMR) showed a positive correlation with the number of nodules in the secondary root (NSR) $(\mathrm{P}<0.05$ and $\mathrm{P}<0.01)$ and root dry mass (RDM) 05 and $\mathrm{P}<0.01)$ at 15 and $30 \mathrm{DAE}$, respectively. It is seen that the larger the root system, the greater the amount of secondary roots and the greater the chance of nodule formation in these. Root nodulation is directly related to the supply of nutrients to the common bean, especially nitrogen. In the present study, secondary root nodulation (NRS) was more relevant for production, since it presented a positive correlation $(\mathrm{P}<0.05)$ at $15 \mathrm{DAE}$ and highly significant $(\mathrm{P}<0.01)$ at $30 \mathrm{DAE}(\mathrm{SM})$, it is worth noting that the dry mass of the nodules $(\mathrm{DMN})$ showed a significant positive correlation with grain yield (PROD) at 30 DAE (Table 8 and Table 9).

The pod length showed a positive correlation $(\mathrm{P}<0.01)$ for the number of grains per pod and $(\mathrm{P}<0.05)$ for the pod numbers, since the higher $\mathrm{CV}$ will condition the greater chance of grain development (Table 10).

The residual dose of $80 \mathrm{~kg} \cdot \mathrm{ha}^{-1}$ of $\mathrm{P}_{2} \mathrm{O}_{5}$ promoted higher grain yield, around 393.5 Mg.ha ${ }^{-1}$ (Table 8), possibly due to higher production of pods per plant. The highest mean obtained in the test, despite being below the national average $\left(410 \mathrm{Mg} \cdot h \mathrm{~h}^{-1}\right)$, Northeast (404 Mg.ha ${ }^{-1}$ ) and Maranhão (468 Mg.ha ${ }^{-1}$ ), according

Table 8. Linear correlation between plant height $(\mathrm{PH})$, main root length (MRL), main root nodules (MRN), secondary root nodules (SRN), dry root mass (DRM), nodule dry mass NDM), dry mass of the area (DMA), leaf area (LA) and productivity (PROD) at 15 DAE.

\begin{tabular}{cccccccccr}
\hline & PH & MRL & MRN & SRN & DRM & NDM & DMA & LA & PROD \\
\hline AP & 1.00 & & & & & & & & \\
CRP & 0.02 & 1.00 & & & & & & & \\
NRP & -0.11 & 0.21 & 1.00 & & & & & & \\
NRS & 0.21 & -0.23 & $0.44^{*}$ & 1.00 & & & & & \\
MSR & 0.02 & 0.02 & $0.67^{* *}$ & $0.86^{* *}$ & 1.00 & & & & \\
MSN & $0.50^{*}$ & 0.23 & 0.05 & 0.00 & 0.02 & 1.00 & & & \\
MSPA & $0.49^{*}$ & 0.31 & 0.05 & -0.03 & 0.00 & $0.71^{* *}$ & 1.00 & & \\
AF & $0.49^{*}$ & -0.03 & 0.07 & 0.27 & 0.19 & $0.42^{*}$ & $0.44^{*}$ & 1.00 & \\
PROD & $0.44^{*}$ & 0.01 & 0.13 & $0.51^{*}$ & 0.39 & 0.03 & 0.04 & 0.18 & 1.00 \\
\hline
\end{tabular}

${ }^{\star}$ Significant at $5 \%$ probability by the $t$ test; ${ }^{*}$ Significant at $1 \%$ probability by $\mathrm{F}$ test. 
Table 9. Linear correlation between plant height $(\mathrm{PH})$, main root length (MRL), main root nodules (MRN), secondary root nodules (SRN), dry root mass (DRM), nodule dry mass (NDM), dry mass of the area (DMA), leaf area (LA) and productivity (PROD) at 30 DAE.

\begin{tabular}{cccccccccc}
\hline & AP & CRP & NRP & NRS & MRN & MSR & MSPA & AF & PROD \\
\hline AP & 1.00 & & & & & & & & \\
CRP & 0.19 & 1.00 & & & & & & & \\
NRP & 0.12 & 0.23 & 1.00 & & & & & & \\
NRS & 0.32 & 0.14 & $0.62^{* *}$ & 1.00 & & & & & \\
MSR & 0.18 & 0.00 & $0.47^{*}$ & $0.85^{* *}$ & 1.00 & & & & \\
MSN & $0.45^{*}$ & -0.03 & -0.13 & -0.11 & -0.16 & 1.00 & & & \\
MSPA & $0.57^{* *}$ & 0.12 & -0.22 & 0.00 & 0.06 & $0.62^{\star}$ & 1.00 & & \\
AF & $0.55^{* *}$ & 0.02 & 0.29 & $0.70^{* *}$ & $0.67^{* *}$ & 0.37 & $0.42^{*}$ & 1.00 & \\
PROD & 0.24 & -0.19 & 0.27 & $0.55^{* *}$ & $0.45^{*}$ & 0.21 & 0.22 & $0.47^{\star}$ & 1.00 \\
\hline
\end{tabular}

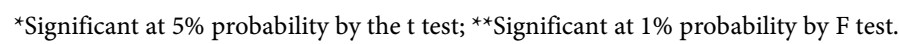

Table 10. Linear correlation between pod length (PL), grains per pod (GP), pod number (PN) and grain yield (GY).

\begin{tabular}{ccccc}
\hline & PL & GP & PN & GY \\
\hline PL & 1 & & & \\
GP & $0.79^{* *}$ & 1 & & \\
PN & $0.48^{*}$ & 0.26 & 1 & 1 \\
GY & 0.33 & 0.2 & 0.47 & 1 \\
\hline
\end{tabular}

${ }^{*}$ Significant at $5 \%$ probability by the $\mathrm{t}$ test; ${ }^{*}$ Significant at $1 \%$ probability by $\mathrm{F}$ test.

Table 11. Economic viability of different doses of residual phosphorus on the productivity of cowpea cultivated in the eastern region of Maranhão.

\begin{tabular}{ccc}
\hline Residual P $\left(\mathrm{kg} \cdot \mathrm{ha}^{-1}\right.$ of $\left.\mathrm{P}_{2} \mathrm{O}_{5}\right)$ & Grain Productivity $\left({\left.\mathrm{Mg} \cdot \mathrm{ha}^{-1}\right)^{*}}\right.$ & Net Revenue (US\$) \\
\hline 0 & $120.48 \mathrm{c}$ & 105.13 \\
60 & $256.32 \mathrm{~b}$ & 210.73 \\
70 & $256.37 \mathrm{~b}$ & 208.47 \\
80 & $393.44 \mathrm{a}$ & 326.26 \\
90 & $295.82 \mathrm{ab}$ & 238.42 \\
100 & $189.37 \mathrm{bc}$ & 142.85 \\
\hline
\end{tabular}

Means followed by the same letter in the column do not differ by Duncan test at the $5 \%$ meaningfulness level. CV: coefficient of variation.

to the data [25], was more advantageous in relation to the others, due to the higher net revenue obtained.

The economic feasibility analysis seeks to identify the expected benefits in a given investment to put them in comparison with the investments and associated costs (Table 11). It can be observed that the dose of $100 \mathrm{~kg} \cdot \mathrm{ha}^{-1}$ of $\mathrm{P}_{2} \mathrm{O}_{5}$ promoted lower net revenue when compared to the other treatments, except in 
relation to the control, due to the high price for simple superphosphate and low prices of cowpea in the region, and the phosphorus dose corresponding to 80 $\mathrm{kg} \cdot \mathrm{ha}^{-1}$ of $\mathrm{P}_{2} \mathrm{O}_{5}$ promoted higher grain yield (393.44 Mg.ha ${ }^{-1}$ ) and bigger a profit margin.

In general, grain yield in treatments with residual doses of $\mathrm{P}$ was not lower than that obtained in the large crop producing regions, and considerably higher $(\mathrm{P}<0.05)$ than the treatment without addition of $\mathrm{P}$, which presented a productivity of 57, 8\% less than treatment with $100 \mathrm{~kg} \cdot \mathrm{ha}^{-1}$ dose of $\mathrm{P}_{2} \mathrm{O}_{5}$ and $227 \%$ less than the productivity obtained with the $80 \mathrm{~kg} \cdot \mathrm{ha}^{-1}$ dose treatment of $\mathrm{P}_{2} \mathrm{O}_{5}$.

Thus, it can be inferred that in some cases, it is worth making use of the residual phosphorus applied in the predecessor crop, since the use of residual fertilization can favor the fertilizer economy, reduce the leaching of salts to the water table and, consequently, the contamination of rivers and lakes, promoting greater environmental sustainability.

\section{Conclusion}

The cultivation of cowpea in previously cultivated areas is feasible, in order to take advantage of the residual phosphate fertilization in the Cerrado of East of Maranhão, being the dose of phosphorus applied in the predecessor crop (maize) corresponding to $80 \mathrm{~kg} \cdot \mathrm{ha}^{-1}$ of $\mathrm{P}_{2} \mathrm{O}_{5}$ recommended, because it promotes higher yields of cowpea beans and profit margin.

\section{Acknowledgements}

The authors thank the Fundação de Amparo à Pesquisa e ao DesenvolvimentoCientífico e Tecnológico do Maranhão (FAPEMA) (Foundation for Research and Scientific and Technological Development of Maranhao) and the Center for Agricultural and Environmental Sciences of the Universidade Federal do Maranhão (UFMA) (Federal University of Maranhão).

\section{References}

[1] Silva, J.A., Oliveira, A.P.O., Moura, M.F., Silva, J.A. and Araújo, M.A.M. (2014) Efeito residual da adubação fosfatada em três cultivos sucessivos com feijão-caupi Revista Caatinga, 27, 31-38. https://periodicos.ufersa.edu.br/index.php/caatinga/article/view/2864/pdf_168

[2] Silva, M.C., Costa, F.R., Leandro, W.M., Lima Júnior, A.F., Brito, G.S. and Silva, L.R. (2015) Eficiência de uso de termofosfato de alumínio como fonte de fósforo na produção de feijão, em solo incubado. Revista Faculdade Montes Belos, 8, 165-176. http://revista.fmb.edu.br/index.php/fmb/article/view/176/165

[3] Teixeira, P.E.G., Fernandes, A.R., Galvão, J.R., Pereira, W.V.S., Casanova, S.R.A. and Alves Filhos, P.P.C. (2016) Cowpea Yield on Soils with Residues of NPK and Natural Phosphate Fertilizers in Succession the Área of Degraded Pasture. Revista Ceres, 63, 553-567. https://doi.org/10.1590/0034-737X201663040017

[4] Freitas, E.V.S., Nascimento, C.W.A., Goulart, L.D.F. and Silva, J.P.S. (2009) Disponibilidade de cádmio e chumbo para milho em solo adubado com fertilizantes fosfatados. Revista Brasileira de Ciência do Solo, 33, 1899-1907. 
https://doi.org/10.1590/S0100-06832009000600039

[5] Coutinho, P.W.R., Silva, D.M.S., Saldanha, E.C.M., Okumura, R.S. and Júnior, M.L.S. (2014) Doses de fósforo na cultura do feijão-caupi na região nordeste do Estado do Pará. Revista Agro@mbiente On-Line, 8, 66-73. https://doi.org/10.18227/1982-8470ragro.v8i1.1310

[6] Zucarell, C., Silva, R.R., Gazola, D., Chaves, D.P. and Nakawaga, J. (2014) Adubação fosfatada e épocas de cultivo na composição química de sementes de cultivares de feijoeiro. Ciência Rural, 44, 1549-1555. https://doi.org/10.1590/0103-8478cr20131124

[7] Rosa, A., Caponi, L.H. and Zanão Júnior, L.A. (2016) Disponibilidade de fósforo em um Latossolo Vermelho em função do pH do solo. Acta Iguazu, 5, 108-115. http://e-revista.unioeste.br/index.php/actaiguazu/article/viewFile/15975/10870

[8] Parente, T.L., Caioni, S., Lange, A., Caioni, C., Silva, A.C.S., Yamashita, O.M. and Lavezo Neto, A. (2016) Residual de fósforo em cana soca para produção de forragem no norte de Mato Grosso. Revista de Ciências Agroambientais, 14, 157-162. https:/periodicos.unemat.br/index.php/rcaa/article/view/1422/1400

[9] Instituto Nacional de Meteorologia. Inmet. http://www.inmet.gov.br/portal/index.php?r=tempo2/verProximosDias

[10] Santos, H.G., Jacomine, P.K.T., Anjos, L.H.C., Oliveira, V.A., Lumbreras, J.F., Coelho, M.R., Almeida, J.A., Cunha, T.J.F. and Oliveira, J.B. (2013) Sistema brasileiro de classificação de solos. EMBRAPA, Rio de Janeiro, 27-264.

[11] Comissão de Fertilidade do Solo do Estado de Minas Gerais-CFSMG (1999) Recomendação para o uso de corretivos e fertilizantes em Minas Gerais: $5^{\mathrm{a}}$ aproximação. SBCS, Viçosa, 359 p.

[12] The University of Texas Health Science Center in San Antonio (2002) Image Tool. Version 3.0., UTHSCSA, San Antonio, TX, USA.

[13] SAS Institute (2002) SAS Systems for Windows. Version 9. SAS, Cary, NC.

[14] Bezerra, M.A.F., Oliveira, F.A., Bezerra, F.T.C., Pereira, W.E. and Silva, S.A. (2014) Cultivo de feijão-caupi em Latossolos sob efeito residual da adubação fosfatada. $R e-$ vista Caatinga, 27, 109-115.

https://periodicos.ufersa.edu.br/index.php/caatinga/article/view/2816/pdf_92

[15] Oliveira, G.A., Araújo, W.F., Cruz, P.L.S., Silva, W.L.M. and Ferreira, G.B. (2011) Resposta do feijão-caupi as lâminas de irrigação e as doses de fósforo no cerrado de Roraima. Revista Ciência Agronômica, 42, 872-882. http://doi.org/10.1590/S1806-66902011000400008

[16] Raij, B.V. (1991) Fertilidade do solo e adubação. Instituto da Potassio \& Fosfato, Piracicaba, $343 \mathrm{p}$.

[17] Silva, A.J., Uchôa, S.C.P., Alves, J.M.A., Lima, A.C.S., Santos, C.S.V., Oliveira, J.M.F. and Melo, V.F. (2010) Resposta do feijão-caupi à doses e formas de aplicação de fósforo em Latossolo Amarelo do Estado de Roraima. Acta Amazônica, 40, 31-36. http://doi.org/10.1590/S0044-59672010000100004

[18] Boyer, J.S., Silk, W.K. and Watt, M. (2010) Path of Water for Root Growth. Functional Plant Biology, 37, 1105-1105. https://doi.org/10.1071/FP10108

[19] Morais, W.A., Soares, F.A.L., Cunha, F.N., Silva, N.F., Vidal, V.M. and Teixeira, M.B. (2016) Sistema radicular, teores de água e distribuição de fotossimilados no feijoeiro submetidos a variações de adubação e irrigação. Revista Brasileira de Agricultura Irrigada, 10, 533-543. https://doi.org/10.7127/rbai.v10n200391

[20] Soares, M.M., Araújo, E.F., Oliveira, G.L., Silva, L.J. and Soriano, P.E. (2014) Nodu- 
lation and Growth of Soybean Plants as a Function of Coating the Seeds with Phosphorous. Bioscience Journal, 30, 1438-1446.

http://www.seer.ufu.br/index.php/biosciencejournal/article/view/21862

[21] Sa, T.M. and Israel, D.W. (1991) Energy Status and Functioning of Phosphorus-Deficient Soybean Nodules. Plant Physiology, 97, 928-935.

https://www.ncbi.nlm.nih.gov/pubmed/16668533

[22] Milani, G.L., Oliveira, J.A., Silva, L.H.C., Von Pinho, E.V.R. and Guimarães, R.M. (2008) Nodulação e desenvolvimento de plantas oriundas de sementes de soja com altos teores de molibdênio. Revista Brasileira de Sementes, 30, 19-27.

http://www.scielo.br/pdf/rbs/v30n2/a03v30n2.pdf https://doi.org/10.1590/S0101-31222008000200003

[23] de Oliveira, E., Mattar, E.P.L., Araújo, M.L., Jesus, J.C.S., Nagy, A.C.G. and Santos, V.B. (2015) Descrição de cultivares locais de feijão-caupi coletados na microrregião Cruzeiro do Sul, Acre, Brasil. Acta Amazônica, 45, 243-254.

http://doi.org/10.1590/1809-4392201404553

[24] Miranda, P., Costa, A.F., Oliveira, L.R., Tavares, J.A., Pimentel, M.L. and Lins, G.M.L. (1996) Comportamento de cultivares de Vignaunguiculata (L.) Walp., nos sistemas solteiro e consorciado. VI-Tipos ereto e semi-ereto. Pesquisa Agropecuária Pernambucana, 9, 95-105.

http://www.scielo.br/scielo.php?script=sci_nlinks\&ref=000052\&pid=S0102-0536200 800040002300003\&lng=en

[25] Companhia Nacional de Abastecimento (National Supply Company)_CONAB. http://www.conab.gov.br/conteudos.php/conteudos.php?a=1253\&t 